\title{
Types of Factors in Educational Peaceful-Coexistence
}

\author{
Salvador Peiró i Gregòri* \\ Faculty of Education, University of Alicante (Spain) \\ *Corresponding author: salvador.peiro@ua.es \\ Received January 06, 2014; Revised February 06, 2014; Accepted February 12, 2014
}

\begin{abstract}
This article attempts to recompile and systematize before new research. After an introduction on the importance of school's critical climate factors, which are regarding from the quality of teaching? To make this various sources of information are collected. Hence clusters of factors explaining the external and internal causes of school violence are proposed. The provincial scholar reality is explored through the questionnaire. Using descriptive statistics, charts and tables that describe graphs were calculated. Finally, the work has just proposed lines of educational action with respect to factors.
\end{abstract}

Keywords: discipline's educational factors, violence in the educational centres, school's bullying, educational peaceful coexistence

Cite This Article: Salvador Peiró i Gregòri, "Types of Factors in Educational Peaceful-Coexistence.” American Journal of Educational Research, vol. 2, no. 2 (2014): 84-96. doi: 10.12691/education-2-2-4.

\section{Introduction}

From the global socio-cultural perspective, we understand that the coexistence is fundamental for the dynamics of the societies. If democratic systems settle down is to assure the development of people with the biggest respect possible to their dignity. The coexistence in peace is a regulator of the good march of the social interaction. Corollary, the educational institution should take care of the factors to vitalize this by that value. In this sense, the cognitive contents, the affective aspects and the expressive of the educational center must charge sense through an educational ethos.

School violence and educational peaceful coexistence are valued in opposition. In general, an indicator that the coexistence at school is not right occurs when there are assaults, indiscipline, etc. The first researches on this subject consisted on bullying (Olweus, 1978), in France that was called "school violence". The panorama says that that occurs in all schools, regardless of whether has been recognized by staff. In the United Kingdom, Australia and Canada, researchers have found that one in seven students are involved in bullying with $14 \%$ of bullying remaining persistent for six months or more (School Safety; Fuller \& King, 1995) ${ }^{\mathrm{i}}$. The reports are plenty of indiscipline, violence, etc., i.e.: vandalism (7,5\%), physical attack $(7,8 \%)$ and emotional perpetrations $(27,3 \%)$. Those are linked with (and can lead to) others like rejections and social isolations, blackmails, threats, insults, deceives, ridicules, exclusions, manipulations, etc. (Del Rey \& Marchesi, 2005). School violence is becoming a serious problem in recent decades in many countries. The acts include all kinds of assaults that occur within the school, which can be directed or not, relative to those at the educational complex, being them as perpetrators or victims (Houbre, 2005).
In this context the school discipline is an essential element in improving the educational climate. This is because discipline is a mode of life in accordance with laid down rules of the society to which all members must conform, and the violation of which are questionable and also disciplined. It is seen as a process of training and learning that fosters growth and development (Imaguezor, 1997). The aim of discipline is therefore, to help the individual to be well adjusted, happy and useful to his society (Nakpodia, 2010, 145).

We also verify the opportunity of the research as long as it converges with the politics of the administrations of the State. Let us only refer that of the Ministry of Education and other administrations of the school system, to the effects of the articles 124 of the new Law of Education (2013) about organization's norms, stating that the centers will develop a plan for peaceful-coexistence.

Centering the motivation in the educational establishments, we know that teachers manifest a widespread opinion: they are fed up with not being able to carry out their professional task with serenity. Neither a real support is felt from the educational community, neither from headmaster and the administration (Arnaiz, 2003, 61ss). Is this on this way? How does it impact and why? etc.

Therefore, to promote school peaceful-coexistence there is not enough only to transmit not-ethical-knowledge, teachers must to promote positive interactions. For this, it is necessary to know the causes of the negative climate of the classroom, who is involved, causal factors and their interrelationships.

\section{Theoretical Context: Delimitation of the School Violence's Causality in Relationship with the Quality Education's Factors}


From the boy's mistreated perspective, generally, they verify the convergence of factors like: a) the basic outline of the operation of the personal system, b) their interpersonal relationships, mainly with relationship to the primary groups, c) their scale of values, d) the social lists, their number, complexity and consistency in the acting, e) physical strength, and f) the tensions to that children are subjected and the supports of different environment: physical, social, cultural, political, economic, etc. ii Pedagogically it interests us to define the causes of the school difficulty. The most recent contributions confirm our researches line on the topic.

The study of factors such as questions on education, should not be made in the abstract, we should proceed as Nakpodia $(2010,146)$ relative to the rules, something that is so related to the topic at hand. On this way, Marai \& Meier (2010: 45-48) distinguish the following groups of factors: I) Factors related to internal systems: developmental stage of the learner, inexperience or ignorance, curiosity, need for belonging, need for recognition, need for power, and control and anger release. II) Factors related to external systems: those related to the family, concerning to schools, and emanating from society. In this sense, before we had already located a similar clusters (Peiró, 2001-b). We lean on in a bibliographical cast that gathered information on intra non school aspects ${ }^{\mathrm{iii}}$. Reinstating this information, with this work seeks to corroborate the previous discoveries and, if at all, to rectify by the light of the new opposing information.

Researches on many children found four causes of misbehavior: a child seeking attention, power, excitement and revenge. Synthezising INTO (2004) and CDC (2011) we can say that there is a context composed by: A) Children with difficulties on communication, because they have a lack of understanding or ability to use language; including low IQ and deficits in cognitions, informationprocessing habilites... B) The social aspects: children may react negatively to noise, heat and cold or to invasion of their space, particularly children with autistic spectrum disorders. C) Even negative attention can be motivating for some children, especially if they feel that this is the only attention they receive, then their behavior display frustration and boring. D) Children growing up with poor social skills and language development, associated with poor parenting skills may lead to a child exhibiting challenging behavior as a survival way. E) Physiological aspects like pain, illness or sensory difficulties, particularly associated with certain conditions and disabilities such as repeated and involuntary body movements (tics) and uncontrollable vocal sounds (Tourette's Syndrome) or ritualistic or obsessive behavior (Autistic Spectrum Disorders). F) Each one person has his history of violent victimization, with early aggressive deeds, climate of drugs, alcohol or tobacco.

We find another grouping of relative factors to the context and school structures. This includes facilitating to show the negative attitudes learned outside of the classrooms (Hyndman and Thorsborne, 1993).

The more commented fact is the no fulfillment of the norms, school regulations or laws (Rigby, 1996). Some interpersonal relationships are also verified as a characterized by a strong egotism, what blocks the use of the rationality and the dialogue (Alanen, 2003). But, the most abundant reports point out the importance of the context of the family (Peiró, 1997); mainly when the homelike means presents the absence of maternal affectivity (US National Committee on Violence Report, 1990), or presenting poverty in stimuli to alphabetize, at value, etc. which structure an infraculture-low culture, that not means subculture-(Australia Public Policy Research Center, 1988). In this sense, when the home is presented unstructured, the situation it is more inclined to promote negative feelings that are taken to the schools (Rigby \& Slee, 1991).

But, as for the pedagogic view, although the delimitation of the facts helps us to define this problem, we won't act in a systematic way without abiding to a series of factors related with the educational quality. Nevertheless this search, we already advance, it should not be contemplated from the mere predicative outline. We sense the multifaceted causation, there are not lineal neither rigid outlines. Fruit of the documental analysis, we find the following causes of the bad treatments in the educational institutions $^{\mathrm{iv}}$. The influence of diverse factors (Figure 1) has been pondered statistically for Tillmann (2005, 97ss).

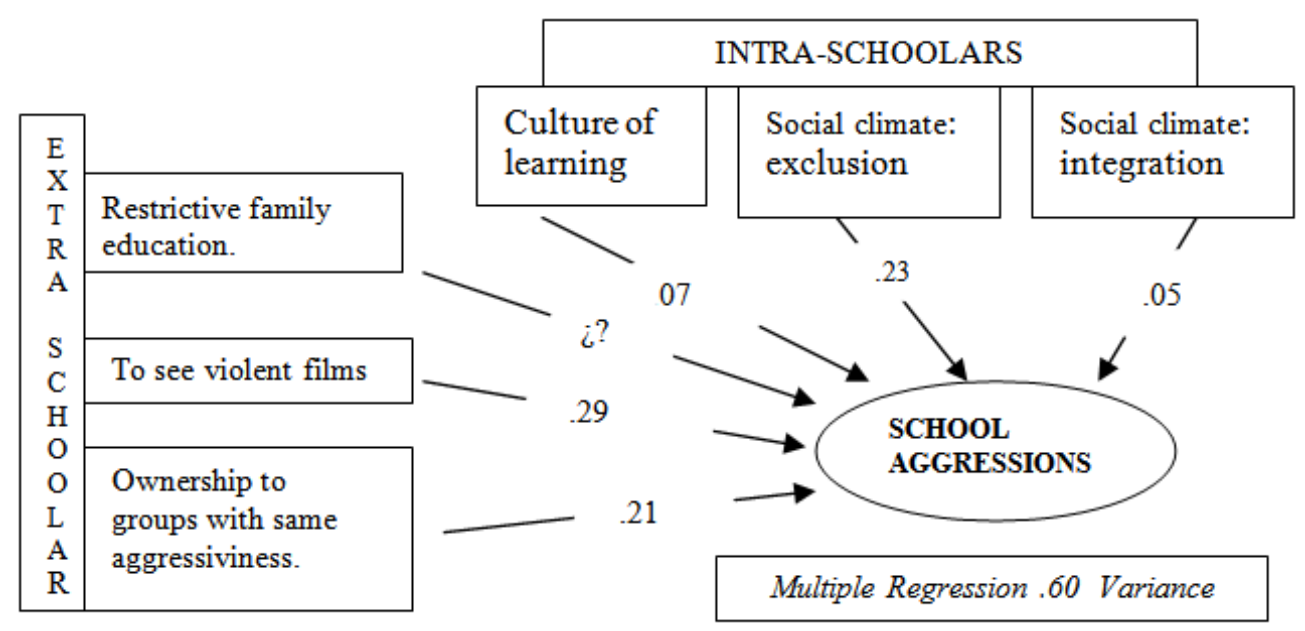

Figure 1. Influences of the factors intra and extra scholars in the physical violence of the schools (Hesse, Germany, 1999, made by Tillmann: 2005, 97ss)

From a consideration of the educational institution and their interrelations with the social-cultural and community context, we can contain the causes of the school violence the following environments: A) Singular aspects are an 
important paper in the boy's aggressive behavior. Certain infantile pathologies that can be related with the aggressiveness also exist like: children with difficulties for the auto control, with low tolerance to the frustration, dysfunction for deficit of attention and hyperactivity, toxic manic, problems of self-esteem, depression, stress, learning difficulties, etc. B) The family is the first environment in that the boy is socialized, he acquires behavior norms and values concerning peacefulcoexistence. Students forme its personality with those, so that this is fundamental for his personal, school and social adjustment, being in the origin of many of the problems of aggressiveness that are reflected in the school environment. For example, Jordanian high school students with more educated parents are less likely to be involved in misbehavior. Also, in terms of misbehavior, they concluded that there is not significant statistical difference between students with varying family income (Mahasneh \& others, 2012, 129). C) The screens of violence, due to the culture in which live full with icons given by cinema, television, mobile, internet or the video games that bombard us continually. D) The climate of the school is co-created by all-together factors, since the peaceful coexistence in each educational center is conditioned by an entire group of rules, some are officials and unofficial other, the regulations that the students' aggressive react or the professors can cause.

From the school we have information that say: As bigger the school could be, greater risk that bullying could occur, especially if this factor is compounded by the lack of physical control, security and respect, humiliation, threats, and exclusion among staff teachers and students. Seeing with Hurrelman (Hanke et al, 1979) and Fernández (1999), there are other factors to be considered: 1) values' crisis in the school itself; 2) uniformity, rigidity and homogenization; 3) a notional overemphasis on student performance and uniformity reference on yields, and to prepare only for certain types of tests, or ignore the objectives achieved in the previous year by the students, and 4) the concentration in classrooms of children and adolescents at risk or troubled.

Also, teachers are moved by structuralism that could be focused only implementing an authoritarian model; already, to going on a routine, or teaching by unethical overspecialization; all of those are causing little sensitivity así comoto the relational and emotional aspects of the pupils, or going on communication with difficulties (Palomero, Fernández, 2001). In an Argentinean research (OAVE, 2009), structuralism and rigidity is related as causing the dissolution of the teacher's authority and the students, the teacher is perceived as a knowledge transmitter, and possessor of knowledge and the student like a "clean slate" knowledge gap to be absorbed from which "teaches" teachers.

We should also mention the "new" educational models, that implement sightlessly the values, also the absence of limits and rules of conduct, all those have influenced these behaviors could occur more frequently. The Report of the Ombudsman (2000 and following) partly responsible teachers, saying they are more concerned with concepts learning problems that to develop the emotional intelligence of students. Likewise, the way on implementing norms or that may not apply frequently, or at other times are a kind of penal codes (Cerrón, 2000, 15); those already may make difficult the peaceful-coexistence or cause aggressive reactions.

We can also deduce the reasons for the improper performance of teachers. One is ignorance of the conflict's causes and the transformation of the problems in the form of the spiral of violence education. Others follow on to act intuitively, or following some customary practices, which are often copy of others practiced by the teachers they had at similar age. Another shall be looking at the inertia, till to say "I can do nothing". A fourth aspect is to keep a reactionary or defensive attitude to school's aggression. They are trying to control students, isolate them, expelling the problematic to the hall or at home. All this is summarized in not understanding the axiological school roots of positive climate for learning. Those before explanations accounted for by that teachers are increasingly isolated situation (ANPE, 2011). Therefore, the causal explanation is necessary to train future teachers.

Looking inside the school, previous research fails on defining the school culture or its climate of exclusion (which is ejected and why?), and what promotes integration? Consequently: some questions may be formulated. One: if the educational reality could provide results that the theoretical framework of the research has adduced. Also, it could be possible to classify the induced information in scholastic factors' sets, according con the opinion of stakeholders? Also, we wonder if there are similarities or dissimilarities in different years and school strata.

\section{Research}

\subsection{Methodology}

The methodologies must be appropriate with the objectives and strategies, as well as the nature of the reality where is applied. The used methodologies are and consist of:

a) For the introduction and theoretical context, the analytical language to study and documentation with the purpose of making analysis of stories, newspapers, journals, etc. is used. As wel as grouping variables as sets, in order to have a consistent clusters of questions, for to facilitates the interpretation of data.

b) The empirical way consists of an descriptiveexplanatory. This was used with the purpose of interpreting surveys with relationship to the factors, through specific questionnaires. Be enough to apply the EXCEL or, more complexly, the statistical package SPSS, with the purpose of validating questions, questionnaires, localization of "clusters".

c) The use of reasoning with phenomenology as a last methodological. As it is part of the whole work, could be specifically used here with synthetic focus. To compose and design the questionnaire was followed an analyticalsynthetically (phenomenological) reflection. It is to think locally in the global of the educational and virtually located action in a school center. By this way, we will make the discussion and elaboration of conclusions and proposals ${ }^{\mathrm{v}}$.

\subsection{Concerning the Empirical Way}


3.2.1. The population implied in the study of the cases are students, teachers and parents. The total was 792 persons. The distribution of the population by year and type, as well as the confidence level of the results, is shown by the below tables. The Table 1 corresponds to the educational responsibility of the consulted people.

Table 1. The population's distribution by type and year \& level of trust

\begin{tabular}{|l|c|c|c|c|c|c|c|c|c|c|}
\hline & $\mathbf{2 0 0 3}$ & $\mathbf{2 0 0 4}$ & $\mathbf{2 0 0 5}$ & $\mathbf{2 0 0 6}$ & $\mathbf{2 0 0 7}$ & $\mathbf{2 0 0 8}$ & $\mathbf{2 0 0 9}$ & $\mathbf{2 0 1 0}$ & $\mathbf{2 0 1 1}$ & $\mathbf{2 0 1 2}$ \\
\hline n surveyed & $\mathbf{1 5 9}$ & $\mathbf{1 5 6}$ & $\mathbf{9 5}$ & $\mathbf{5 2 7}$ & $\mathbf{2 6 1}$ & $\mathbf{1 2}$ & $\mathbf{4 1}$ & $\mathbf{2 4}$ & $\mathbf{3 1}$ & $\mathbf{1 1}$ \\
\hline Teacher & 105 & 120 & 63 & 424 & 8 & 7 & 21 & 4 & 7 & 3 \\
\hline Director & 2 & 2 & 0 & 2 & 0 & 0 & 0 & 0 & 2 & 0 \\
\hline Head-master & 4 & 0 & 0 & 2 & 1 & 0 & 0 & 0 & 0 & 0 \\
\hline Father & 8 & 3 & 0 & 12 & 20 & 0 & 0 & 8 & 9 & 6 \\
\hline Mather & 9 & 6 & 1 & 6 & 2 & 0 & 0 & 2 & 0 & 1 \\
\hline Tutor & 11 & 11 & 27 & 42 & 26 & 2 & 3 & 9 & 7 & 1 \\
\hline Student & 15 & 10 & 1 & 24 & 193 & 0 & 3 & 0 & 3 & 0 \\
\hline Not specified & 5 & 4 & 3 & 15 & 11 & 3 & 14 & 1 & 3 & 0 \\
\hline Margin of error (to a level of confidence 95\%) & $7,8 \%$ & $7,8 \%$ & $10,1 \%$ & $4,3 \%$ & $6,1 \%$ & $28,3 \%$ & $15,3 \%$ & $20,0 \%$ & $17,6 \%$ & $29,6 \%$ \\
\hline
\end{tabular}

It is impossible to make studies totally designed according to the procedure of representative sampling. There is because the people have lack of enthusiasm in answering to questionnaires that demand certain grade of attention and complexity. Neither, staff commonly is excited to reflect relative problematic situations to their teaching, mainly when they concern to features that touch with problems of psychic health. For enough educational, to apply time to answer to these reagents means to subtract him for other professional tasks, valuing that it is little what receive for this effort (Castanedo, 1993). Consequently, we have not opted for samplings for quota or intentionally foreseen. I invited to participate at random, according to "available fellows to collaborate" for convenience or chance. We know that this procedure is not compactly perfect, but it is the one that more usually are used (Polit \& Humgler, 1997, 238-239).

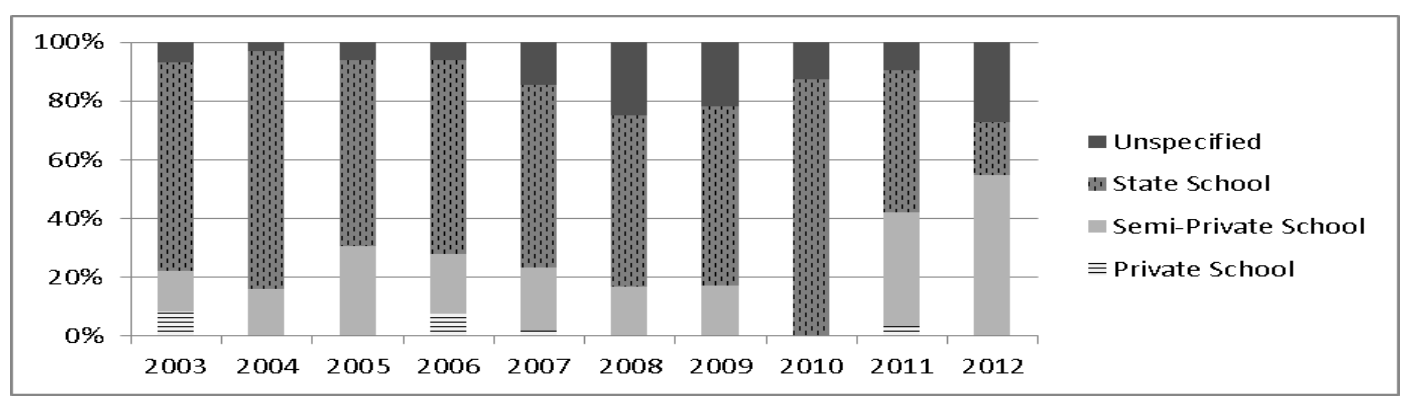

Figure 2. Centres consulted \%, according to cycles \& responsibility

Table 2. Centres consulted \%, according to cycles \& responsibility

\begin{tabular}{|c|c|c|c|c|c|c|c|c|c|c|}
\hline & \multicolumn{2}{|c|}{2003} & \multicolumn{2}{|c|}{2004} & \multicolumn{2}{|c|}{2005} & \multicolumn{2}{|c|}{2006} & \multicolumn{2}{|c|}{2007} \\
\hline & $\mathbf{N}$ & $\%$ & $\mathbf{N}$ & $\%$ & $\mathbf{N}$ & $\%$ & $\mathbf{N}$ & $\%$ & $\mathbf{N}$ & $\%$ \\
\hline N surveyed & 159 & $100 \%$ & 156 & $100 \%$ & 95 & $100 \%$ & 527 & $100 \%$ & 261 & $100 \%$ \\
\hline Infantil education & 8 & $5,0 \%$ & 5 & $3,2 \%$ & 1 & $1,1 \%$ & 10 & $1,9 \%$ & 15 & $5,7 \%$ \\
\hline Primary & 78 & $49,1 \%$ & 35 & $22,4 \%$ & 27 & $28,4 \%$ & 199 & $37,8 \%$ & 35 & $13,4 \%$ \\
\hline Secondary & 41 & $25,8 \%$ & 56 & $35,9 \%$ & 62 & $65,3 \%$ & 286 & $54,3 \%$ & 163 & $62,5 \%$ \\
\hline Bach. & 5 & $3,1 \%$ & 54 & $34,6 \%$ & 1 & $1,1 \%$ & 13 & $2,5 \%$ & 20 & $7,7 \%$ \\
\hline Pre-university & 9 & $5,7 \%$ & 0 & $0,0 \%$ & 0 & $0,0 \%$ & 0 & $0,0 \%$ & 12 & $4,6 \%$ \\
\hline Professional & 8 & $5,0 \%$ & 1 & $0,6 \%$ & 0 & $0,0 \%$ & 1 & $0,2 \%$ & 1 & $0,4 \%$ \\
\hline Not specified & 10 & $6,3 \%$ & 5 & $3,2 \%$ & 4 & $4,2 \%$ & 18 & $3,4 \%$ & 15 & $5,7 \%$ \\
\hline Privated & 13 & $8,2 \%$ & 0 & $0,0 \%$ & 0 & $0,0 \%$ & 39 & $7,4 \%$ & 5 & $1,9 \%$ \\
\hline Concertated & 22 & $13,8 \%$ & 25 & $16,0 \%$ & 29 & $30,5 \%$ & 107 & $20,3 \%$ & 56 & $21,5 \%$ \\
\hline Estatal & 113 & $71,1 \%$ & 126 & $80,8 \%$ & 60 & $63,2 \%$ & 348 & $66,0 \%$ & 162 & $62,1 \%$ \\
\hline \multirow[t]{3}{*}{ Not specified } & 11 & $6,9 \%$ & 5 & $3,2 \%$ & 6 & $6,3 \%$ & 33 & $6,3 \%$ & 38 & $14,6 \%$ \\
\hline & \multicolumn{2}{|c|}{2008} & \multicolumn{2}{|c|}{2009} & \multicolumn{2}{|c|}{2010} & \multicolumn{2}{|c|}{2011} & \multicolumn{2}{|c|}{2012} \\
\hline & $\mathbf{N}$ & $\%$ & $\mathbf{N}$ & $\%$ & $\mathbf{N}$ & $\mathbf{N}$ & $\%$ & $\mathbf{N}$ & $\%$ & $\mathbf{N}$ \\
\hline $\mathrm{N}$ surveyed & 12 & $100 \%$ & 41 & $100 \%$ & 24 & 12 & $100 \%$ & 41 & $100 \%$ & 24 \\
\hline Infantil education & 0 & $0,0 \%$ & 4 & $9,8 \%$ & 10 & 0 & $0,0 \%$ & 4 & $9,8 \%$ & 10 \\
\hline Primary & 5 & $41,7 \%$ & 21 & $51,2 \%$ & 11 & 5 & $41,7 \%$ & 21 & $51,2 \%$ & 11 \\
\hline Secondary & 6 & $50,0 \%$ & 10 & $24,4 \%$ & 3 & 6 & $50,0 \%$ & 10 & $24,4 \%$ & 3 \\
\hline Bach. & 0 & $0,0 \%$ & 2 & $4,9 \%$ & 0 & 0 & $0,0 \%$ & 2 & $4,9 \%$ & 0 \\
\hline Pre-university & 0 & $0,0 \%$ & 0 & $0,0 \%$ & 0 & 0 & $0,0 \%$ & 0 & $0,0 \%$ & 0 \\
\hline Professional & 0 & $0,0 \%$ & 0 & $0,0 \%$ & 0 & 0 & $0,0 \%$ & 0 & $0,0 \%$ & 0 \\
\hline Not specified & 1 & $8,3 \%$ & 4 & $9,8 \%$ & 0 & 1 & $8,3 \%$ & 4 & $9,8 \%$ & 0 \\
\hline Privated & 0 & $0,0 \%$ & 0 & $0,0 \%$ & 0 & 0 & $0,0 \%$ & 0 & $0,0 \%$ & 0 \\
\hline Concertated & 2 & $16,7 \%$ & 7 & $17,1 \%$ & 0 & 2 & $16,7 \%$ & 7 & $17,1 \%$ & 0 \\
\hline Estatal & 7 & $58,3 \%$ & 25 & $61,0 \%$ & 21 & 7 & $58,3 \%$ & 25 & $61,0 \%$ & 21 \\
\hline Not specified & 3 & $25,0 \%$ & 9 & $22,0 \%$ & 3 & 3 & $25,0 \%$ & 9 & $22,0 \%$ & 3 \\
\hline
\end{tabular}




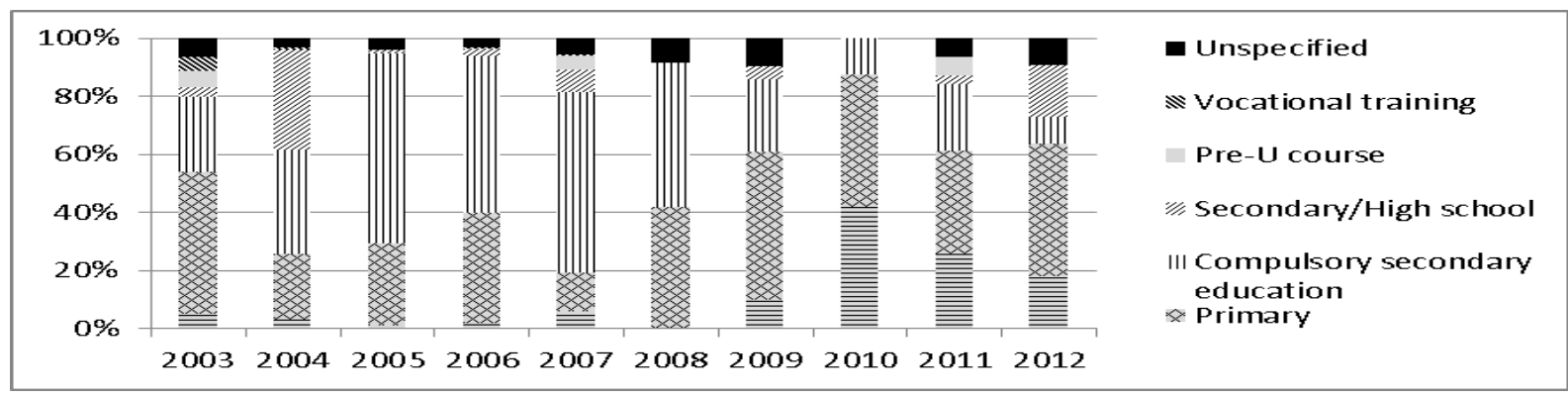

Figure 3. Types os kind of studies: not specified, professionalization, prep-university, baccalaureate, compulsory secondary education, primary

\subsubsection{Questionnaire and Tools}

After a pilot project in a secondary school, on 2000, the full questionnaire consists of 35 items, prepared for be answered according to a Likert scale, which is scored from 1 (never) to 5 (always). Then, each question has grouped in seven clusters, those was composed by a phenomenological reflection, whose names of each item's group are: I. Incorporation of uncivil behaviour from outside the center. II. Discordance between society and school. III. Defective informal education. IV. Excessive specialization. V. Excessive school bureaucracy. VI. Structuralism versus cohesion. VII. Crisis on classrooms aims.

\subsubsection{Mechanical Procedure}

The different users have participated on-line questionnaires using the http://www.violencia.dste.ua.es/. There is possible to consult the questionnaire in the file "VIOLENCIA ESCOLAR", the questionnaire $\mathrm{n} 3$. This system presents several advantages: First, it provides entrances (input) and exits (output) standard. The input allows design programs and statistical software to analyze the data in an automatic way. On the other hand, the standard output guarantees the comparability of different studies. Results can be compared along the time (longitudinal studies), or in different centers (transversal studies), etc. Another advantage of this methodology is it allows work with multiple users (centers, institutes) and multiple projects at the same time. Using the mechanism of extraction of data, different researchers can work in totally different projects starting from the same database.

For to imputing data, we provide a password to students, teachers, parents and tutors of each center. You should inter using this special password: p_estudio. With that entrance code, each one consented to the questionnaires to give their answer, except the special password, because it is not operative. To guarantee the quality and perseverance for to fulfil, the data was facilitated to complete the questionnaires in different moments. This way, the interviewed can only stuff partially the questionnaires, to keep their work to leave WEB, and to connect again, so many times it was necessary, to complete the questionnaires. This is an added positive to the methodology, because this way are tried to minimize the errors due to the fatigue or to the lack of concentration.

A webmaster person (statistical and computer scientist) independent, belonging to a private company situated 100 $\mathrm{km}$, manages and processes data, keeping the whole system.

\subsubsection{Statistic Limitations}

With the purpose of valuing the data, we formulate the value $\mathrm{T}$ that discriminates against validity of disability of toils to $95 \%$. We know that the value that appears is the probability-P-associated to the $\mathrm{T}$ of Student. The general interpretation should be made this way. It is to prove a hypothesis is that there is no significant difference among the stockings of two populations. The $\mathrm{P}$ is obtained, meaning the probability that the hypothesis is certain. That P has a level of trust of $95 \%$, for that, that if it is smaller than 0,05 , one has that the hypothesis is false. This is to say: if the value is bigger than 0,05 , the difference of stockings will be not significant; but if the value is smaller than 0,05 , the difference of stockings can signify.

3.2.5. The survey procedure was as follows. With surveys we are causing a phenomenological reflection on the intellect of the respondents. Pollsters had followed up a specialization course on "discipline, values and school violence". Respondents, before answering to the questionnaire on causal factors, had responded to another on the defining variables of convivial-educational problems (in the mentioned web, this is the questionnaire No. 1). Therefore, when they respond to the factors, are relating the educational quality of school's peacefulcoexistence and educational causes of violence.

\section{Founds}

Regarding previous researches, findings reaffirm the clusters (Figure 4), but these show some variation in its meaning. Cluster I: scores (average 2, 45) display there is no clear and severe contradiction between social demands and school practices. Cluster II: scores $(1,92)$ explain that there are family influence on the climate into schools, but that's clearly not decisive. Cluster III: scores $(2,26)$ show some defective informal education. Cluster IV: scores (2, 11) summarize the involvement of teachers in the socialization and morals processes of students, but with some lacks. Cluster V: scores $(3,45)$ manifest the bureaucratization of school activity is clearly observable. Cluster VI: The structuralism (average scores 2, 31) usually happens in all years except in 2008. Cluster VII: The average of scores $(2,36)$ shows there are problems concerning learning aims.

The cluster-I (Misbehaviors are incorporated) consists of the following two items: 1.1. Defects or customs outside schools cause a bad environment into classrooms. The averages for each of the ten years are: 2,94 -3,08 $2,66-2,56-3,11-3,13-2,50-2,93-2,44-3,00$. These could show the external influence on the climate of the classroom. The overall average is 2,6, not reaching the median, which means "sometimes" it happens. The second 
item's averages (1.2. There are gang influences that pressure on students to cause movements, noises, etc.) $2,62-2,46-2,22-2,16-2,67-2,25-1,77-2,50-2,39$ $-2,00$. The overall average is 2.4 , not reaching the median, which means they are closer to "almost never" that "sometimes" the elements of cluster-I happen. See it in the Figure 4, below.

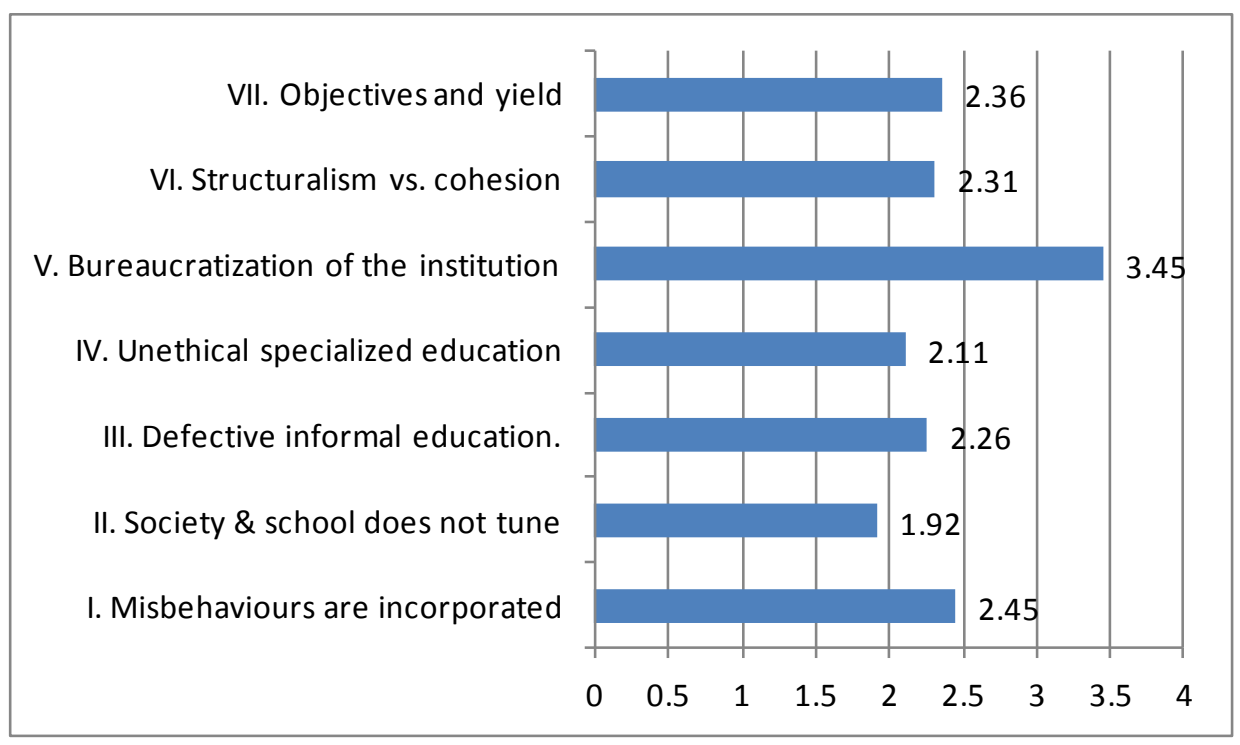

Figure 4. Average of seven clusters

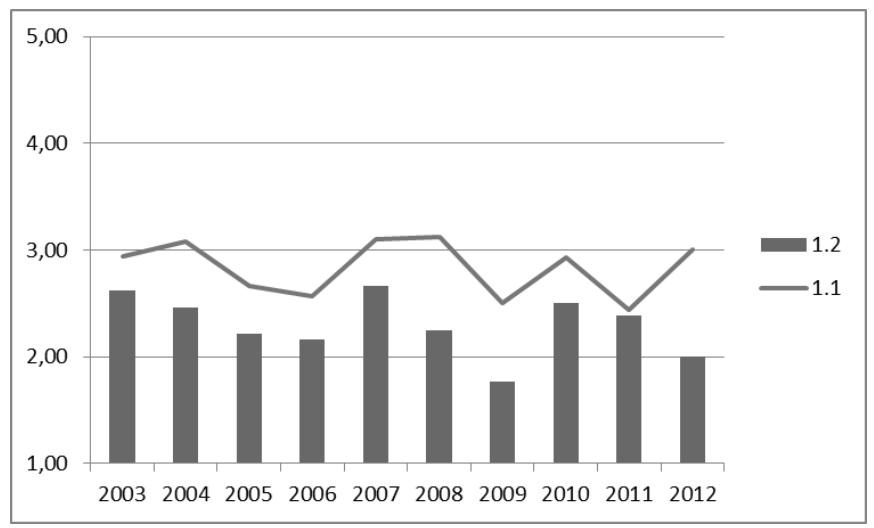

Figure 5. Cluster I: Misbehaviours from out school

On cluster-II (Figure 6 below), scores display there is no clear contradiction between social demands and school practices. However, the absence of unanimity and some evidence in some respects there are contradictions. The years 2008, 2009 and 2011 show greater concordance, but it occurs not for all the items, but there is compensation among those.

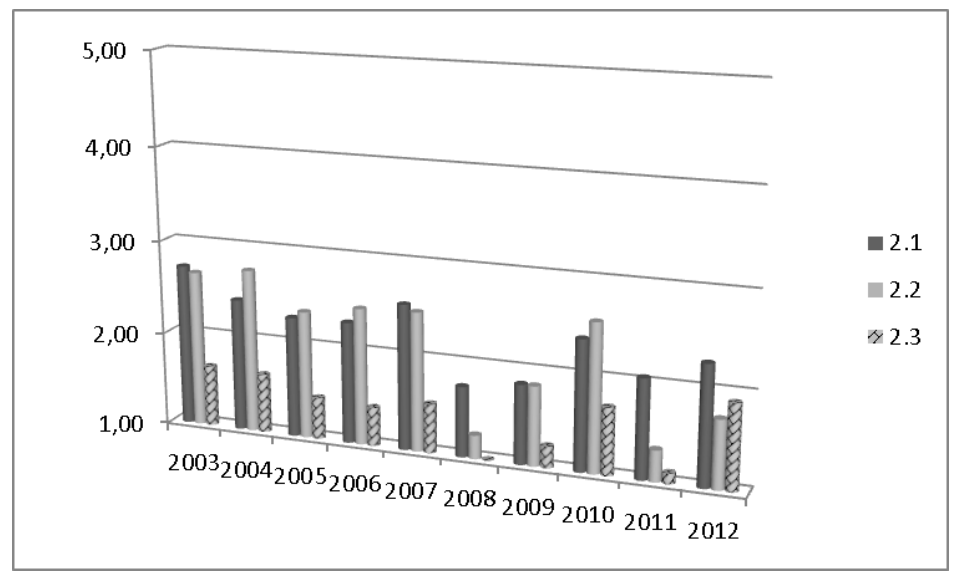

Figure 6. Cluster II: Society vs School?

The recapitulation of the cluster-III (Figure 7) explains that there are family influence on the climate into schools, but that's clearly not decisive. As averages show, scores are placed between "sometimes" and "almost never", 
except the first, that is referring a excessive abuse, which is not located at 1.00 ("never"). From the above, we can say that there are some -not many, not least majority- subjects that brings attitudes that influence the classrooms' climate and disrupt lessons.

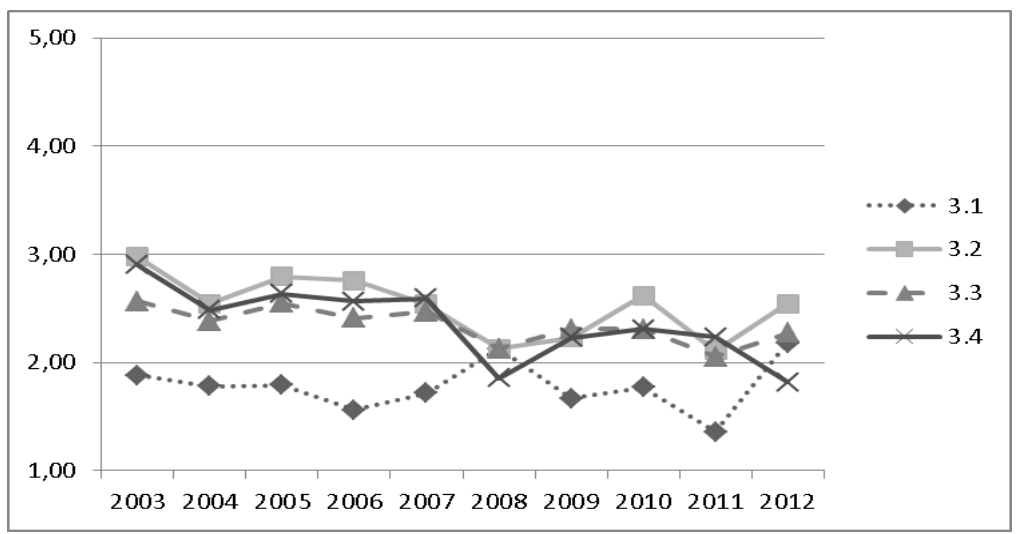

Figure 7. Cluster III: Defective informal education

The cluster-IV (Figure 8, below) summarizes the involvement of teachers in socialization and moral students' acts. The answers to the questions formulated negatively denote that almost never makes such misunderstandings on convivial settings. However, this "almost" denotes something happens $(1,78)$, especially in years 2008 \& 2012. Those are glow by the averages of item 3.2) some parents spoil their children $(2,53)$, or item $3.3)$ there is some negligence $(2,34)$, or item 3.4 ) lack of self-control $(2,39)$. The data spread somewhat, but usually occurs between towards always being almost always a kind of average value. The bureaucratization of school activity is clearly observable.

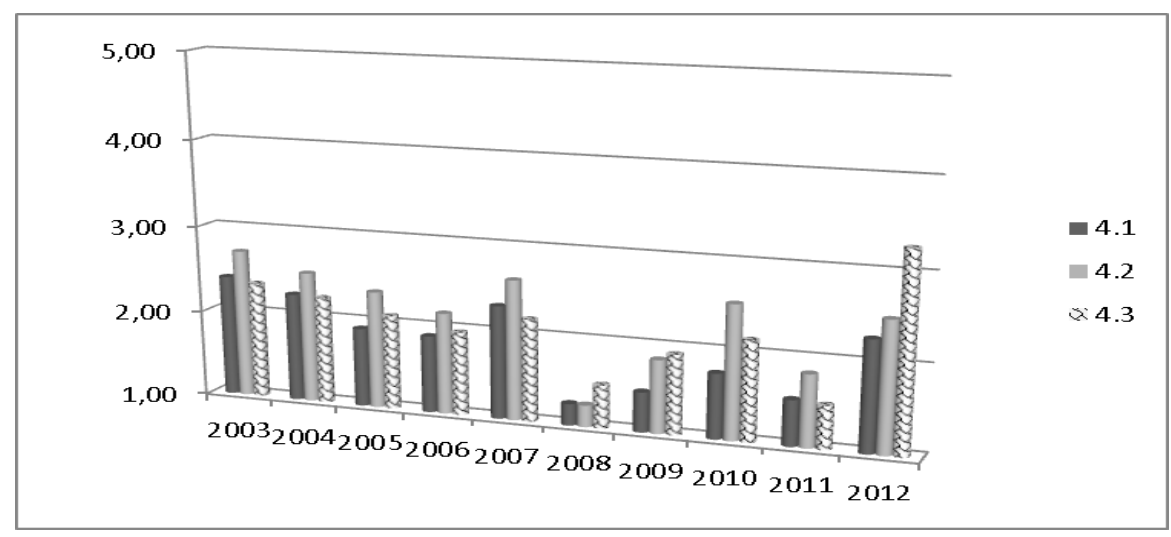

Figure 8. Cluster IV: Teaching's way

Below (Figure 9), on the cluster V, the school bureaucracy is weighted places the score for each cluster's item: regulations (3.72) times (4.09), controls (3.82), functional skills (3.59), demography (2.80), procedures (3.42) and administrators (2.74). It spreads somewhat, but usually occurs between towards always being almost always a kind of average value (the general average is 3 , 45). The bureaucratization of school activity is clearly observable.

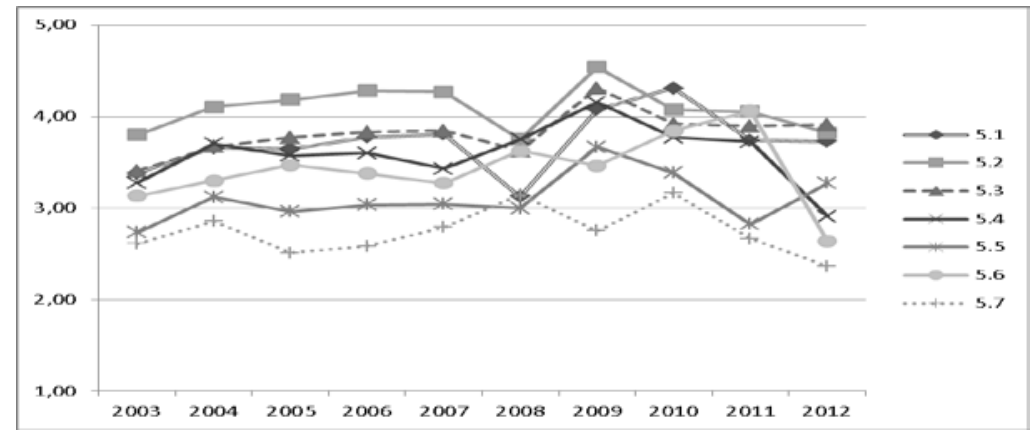

Figure 9. Weiht of cluster V: the school's bureaucratization

On the structuralism, the Figure 10 respect cluster-VI, as the questions were formulated in a negative way, the set of averages are situated a third point under the median (value $=2$, 31) Lickert scale 1-5. Only affirmative (6.3 -3,
39- and $6.53,16)$ are written on this midpoint. Those mean "usually happen" in all years except in 2008, which coincides in all, keeping their level. 


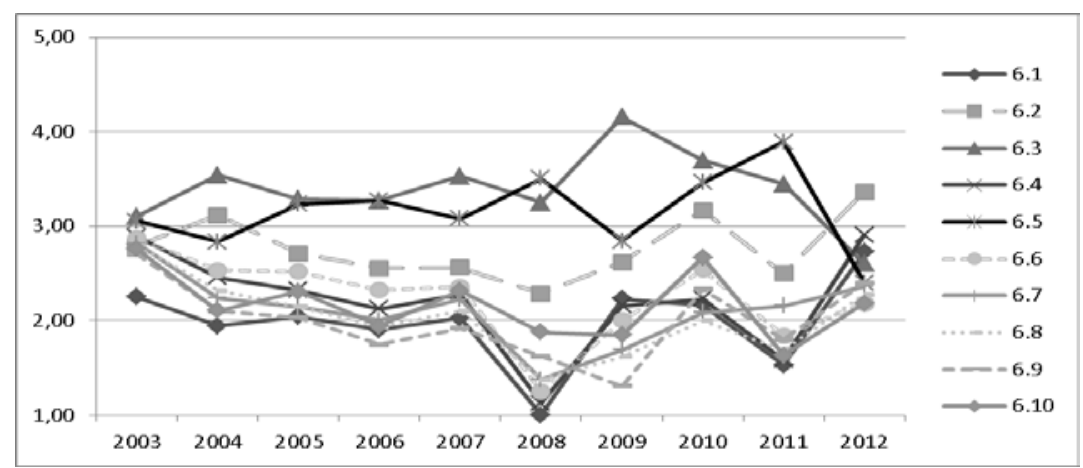

Figure 10. Cluster-VI's items: Educational structuralism

Concerning educational aims, the Figure 11, the clusterVII shows some dissimilarity regarding three items (7.3, $7.4 \& 7.5$ ) respect the 7.6 (the line located above all), for in the last if that would be required between the normal and almost always what is said above almost never. Perhaps, through interviews, is reached clarify if teachers could know how teaching values.

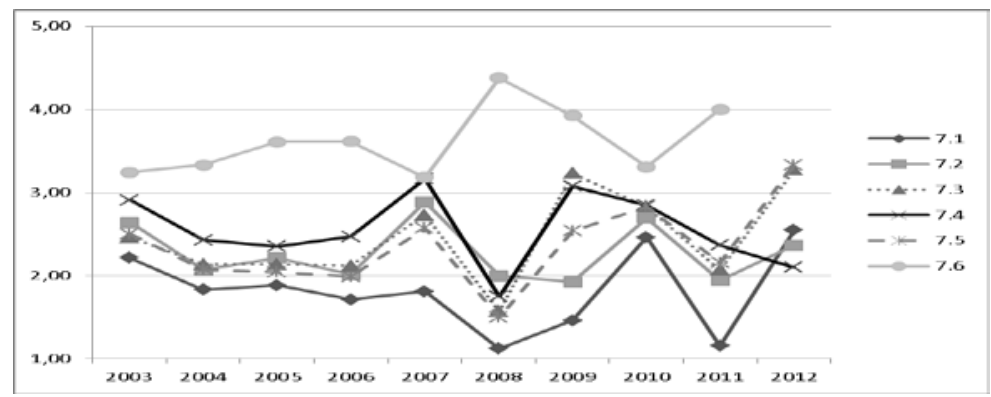

Figure 11. Cluster-VII: ends of learning

In sum it, the results can't read as a mechanical way, but like an accumulation of aspects that are doing twist acts, giving place to a reality prepared in multiple faces. Anyway, by Figure 12 represents, two areas of factorial groups are verified: A) First clusters show the influence of the informal education, being the family the principal responsible. B) Other four latest derivate of focuses professionals, each one denote a kind of reductionism of the educational process.

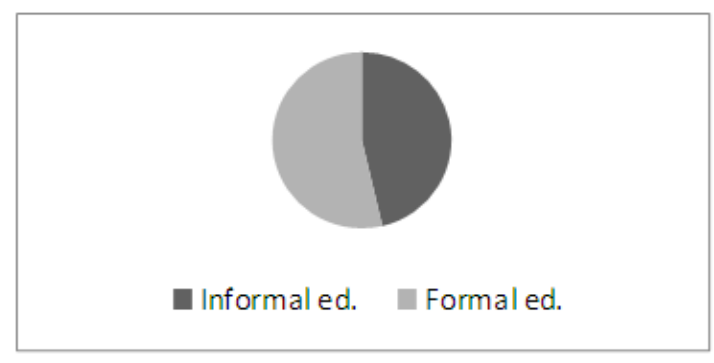

Figure 12. Two main groups: formal \& informal education

Regarding the first three clusters related to the influence of informal education (primary socialization, television's influence, gangs, video, mobile, etc.), the Figure 13 below expresses the distribution of averages show greater similarity between parents and teachers, more than the students with those before, although the position of the students do not withdraw from the educators.

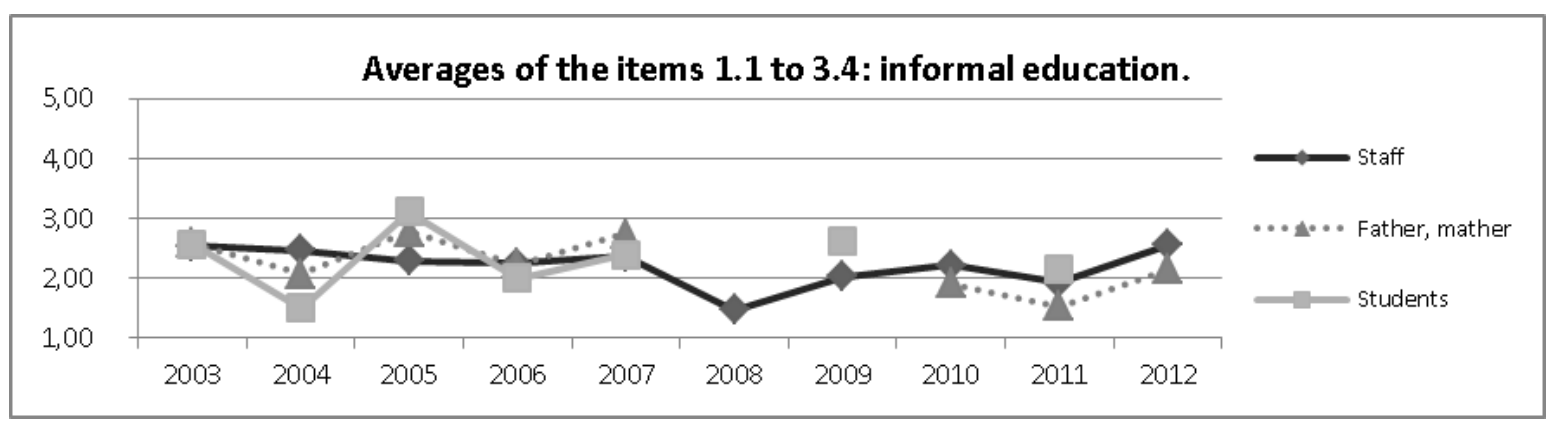

Figure 13. 
As shows the below Figure 14 on items related to formal education, the global average of the last four overlapping clusters are given in the formal education. It almost gives us an overlap.

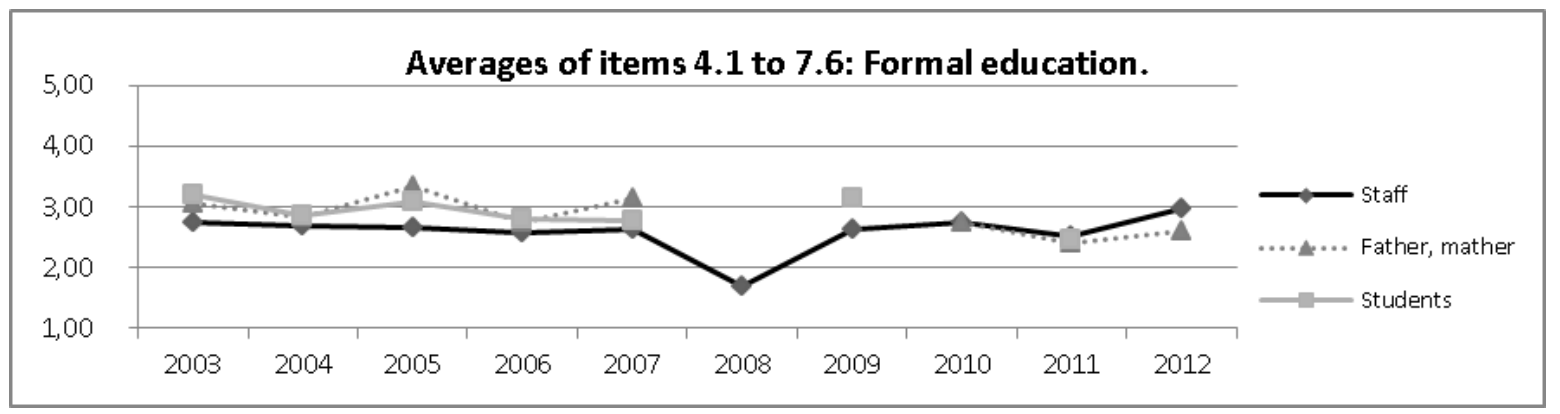

Figure 14.

\section{Discussion}

Does it agree our research findings with studies reported in the theoretical context?, Are our questions resolved?

About the first clusters' group A), there are theoretical currents that emphasize the causes of the aggressions in reason to the frustration of the expectations that pupils feel (Imaguezar, 1997). Trong has revised statistics on acts of violence in different French regions, and its conclusion is that: "the school violence is not more than it leaves of a more extended antisocial behavior that also manifests against porters, tradesmen, drivers of buses and policemen (...) these maladaptive behaviors don't constitute any necessity to be expressed (...) but rather they are steps toward the social decomposition, toward the negative of accepting any type of social authority..." (Trong, 2000, 32). This posture is very questioned at the present time, because researchers forget to the victims, it subtracts importance to the micro sociological analyses and it doesn't coincide with the predominant form of conceiving the current state of the society (Debarbieux, 1999; Furlan, 2003). Is merely it a lineal explanation? The groups of factors no confirm the above "sparsely" mentioned in the theoretical part of the context. There are certain indicators, but those are neither serious nor widespread.

Considering the second clusters' area of factors B), seeing the Olweus (1993) staments, as well others mentioned (Withney \& Smith, 1994; Debarbieux, 1999, or Blaya, 2001) too initially. The last three groups' variables (V, VI \& VII) are the most rated, especially on the bureaucracy, founds confirm Arnaiz (2003). Interpreting this from the historical perspective and the authors mentioned, the weight of a rigidly organized school system is present. It is not taking into account that the school violence varies from a center to other, independently of the socioeconomic characteristics and of the size of the center. In other hand, there are sociocultural conditions that rebound on the school teaching that emphasizes the internal dysfunctions of each institution. Here it is necessary to mention the limits: organization and political life, mutations ecologicalsystemic, new epistemologies and their incidence in the preparation of teachers, partner-structural changes, etc., although for this critical concern, doesn't counsel uniformity.
The findings also confirm the influence of intra-school factors (Alamen., 2003; Tillmann, 2005, etc) like an interactive causality. So, as Debarbieux and collaborators (1999, cap. 6) as well as Blaya (2005, 84-85) consider, the indiscipline and the violent episodes proliferates like a spiral of level to grave misbehaviours, we understand the beginning of the vicious cycle of the indiscipline and violence is in the crisis of values, be in the student, be in teaching or in the same educating institution. When neglecting the due readjustment of the same ones, we will have consequences: fails, incomprehension and lagoons of later learning, indiscipline and school violence. This lasts with or without undisciplined acts. Consequently, the pedagogic task doesn't consist on operating directly from relative acts to violence, but in to locate the affective warp of the relationship between school and pupils, summing up them in the field of the values.

Neither is strange to the causes the teaching centered exclusively and excessively on programs with only scientific notions, more or less memorized; that acts to the routine way stating: to study for tomorrow the following lesson of the book." To value such model, you can consider the reflection: While they accumulated sciences, news, knowledge on the world and they became polished the technique with which we dominate the matter, it was disregarded the cultivation of other areas of the human knowledge, that they are not the intellect; mainly, it was left to the drift the heart, floating without discipline neither performance on the face of the life. This combination takes us to think about the climate from the common of all them: the social values of such interactions.

The individual factors are not considered, because it is a other sciences concerning.

\section{Limitations of This Study}

On the one hand, we have the limits due to the quantitative. The figures below display descriptive categories of qualitative factors related with the conflicts on educational process. By means of the computerization of the data, it is known the reliability of the made processes. For this we have calculated the " $\mathrm{t}$ " of Student ${ }^{\mathrm{vi}}$, with the purpose of calculating the $\mathrm{p}^{\mathrm{vii}}$. Thus, the cells marked in red are those where the difference is significant. In the Table 3 (study "t" on the averages), there are the results according to each year and items: 
Table 3. Clusters' " $t$ " of Student

\begin{tabular}{|c|c|c|c|c|c|c|c|c|c|c|c|c|c|}
\hline A & 11 & & n) & & 23 & 21 & 23 & 232 & $n_{24}$ & 01 & ? & 2 & 51 \\
\hline & & & & & & & & & & & & & \\
\hline 2003 & 0,092 & 0,035 & 0,343 & $0,10 /$ & 0,000 & 0,000 & 0,029 & 0,004 & 0,213 & 0,000 & 0,307 & 0,000 & 0,000 \\
\hline 2004 & 0,001 & 0,000 & 0,000 & 0,520 & 0,000 & 0,000 & 0,003 & 0,000 & 0,000 & 0,000 & 0,001 & 0,000 & 0,000 \\
\hline 2005 & 0,192 & 0,000 & 0,000 & 0,000 & 0,000 & 0,000 & 0,963 & 0,017 & 0,114 & 0,000 & 0,000 & 0,000 & 0,000 \\
\hline 2006 & 0,000 & 0,000 & 0,000 & 0,000 & 0,000 & 0,000 & 0,390 & 0,000 & 0,000 & 0,000 & 0,000 & 0,000 & 0,000 \\
\hline 2007 & 0,000 & 0,047 & 0,000 & 0,000 & 0,000 & 0,000 & 0,000 & 0,000 & 0,001 & 0,000 & 0,006 & 0,000 & 0,000 \\
\hline 2008 & 0,341 & 0,110 & 0,002 & 0,000 & 0,000 & 0,050 & 0,050 & 0,050 & 0,010 & 0,000 & 0,000 & 0,000 & 0,343 \\
\hline 2009 & 0,070 & 0,000 & 0,000 & 0,000 & 0,000 & 0,000 & 0,036 & 0,069 & 0,036 & 0,000 & 0,000 & 0,001 & 0,000 \\
\hline 2010 & 0,456 & 0,215 & 0,175 & 0,697 & 0,000 & 0,000 & 0,500 & 0,070 & 0,070 & 0,000 & 0,339 & 0,018 & 0,000 \\
\hline 2011 & 0,125 & 0,077 & 0,001 & 0,000 & 0,000 & 0,000 & 0,003 & 0,001 & 0,017 & 0,000 & 0,000 & 0,000 & 0,000 \\
\hline \multirow[t]{2}{*}{2012} & 0,808 & 0,491 & 0,007 & 0,074 & 0,000 & 0,002 & 0,036 & 0,389 & 0,073 & 0,001 & 0,074 & 0,334 & 0,108 \\
\hline & p5.2 & $\begin{array}{l}\text { p5.3 } \\
\end{array}$ & p5.4 & p5.5 & p5.6 & p5.7 & p6.1 & p6.2 & p6.3 & p6.4 & p6.5 & & \\
\hline 2003 & 0,000 & 0,000 & 0,000 & 0,463 & 0,000 & 0,036 & 0,000 & 0,933 & 0,000 & 0,311 & 0,002 & & \\
\hline 2004 & 0,000 & 0,000 & 0,000 & 0,000 & 0,000 & 0,528 & 0,000 & 0,000 & 0,000 & 0,000 & 0,652 & & \\
\hline 2005 & 0,000 & 0,000 & 0,000 & 0,136 & 0,000 & 0,008 & 0,000 & 0,405 & 0,000 & 0,000 & 0,000 & & \\
\hline 2006 & 0,000 & 0,000 & 0,000 & 0,000 & 0,000 & 0,000 & 0,000 & 0,000 & 0,000 & 0,000 & 0,000 & & \\
\hline 2007 & 0,000 & 0,000 & 0,000 & 0,000 & 0,000 & 0,906 & 0,000 & 0,001 & 0,000 & 0,000 & 0,000 & & \\
\hline 2008 & 0,006 & 0,016 & 0,006 & 0,558 & 0,017 & 0,349 & 0,000 & 0,163 & 0,190 & 0,000 & 0,042 & & \\
\hline 2009 & 0,000 & 0,000 & 0,000 & 0,002 & 0,014 & 0,864 & 0,036 & 0,499 & 0,000 & 0,017 & 0,859 & & \\
\hline 2010 & 0,000 & 0,000 & 0,000 & 0,030 & 0,000 & 0,190 & 0,025 & 0,194 & 0,001 & 0,036 & 0,014 & & \\
\hline 2011 & 0,000 & 0,000 & 0,000 & 0,915 & 0,000 & 0,602 & 0,000 & 0,196 & 0,005 & 0,000 & 0,000 & & \\
\hline \multirow[t]{2}{*}{2012} & 0,002 & 0,001 & 0,000 & 0,706 & 0,106 & 0,582 & 0,140 & 0,810 & 0,055 & 0,520 & 0,706 & & \\
\hline & p6.6 & p6.7 & $\begin{array}{l}\text { p6.8 } \\
\end{array}$ & $\begin{array}{l}\text { p6.9 } \\
\end{array}$ & p6.10 & p7.1 & p7.2 & p7.3 & p7.4 & p7.5 & p7.6 & & \\
\hline 2003 & 0,365 & 0,851 & 0,931 & 0,255 & 0,639 & 0,000 & 0,059 & 0,000 & 0,186 & 0,000 & 0,000 & & \\
\hline 2004 & 0,002 & 0,000 & 0,000 & 0,000 & 0,000 & 0,000 & 0,000 & 0,000 & 0,000 & 0,000 & 0,000 & & \\
\hline 2005 & 0,006 & 0,000 & 0,000 & 0,000 & 0,000 & 0,000 & 0,000 & 0,000 & 0,000 & 0,000 & 0,000 & & \\
\hline 2006 & 0,000 & 0,000 & 0,000 & 0,000 & 0,000 & 0,000 & 0,000 & 0,000 & 0,000 & 0,000 & 0,000 & & \\
\hline 2007 & 0,000 & 0,000 & 0,000 & 0,000 & 0,000 & 0,000 & 0,216 & 0,336 & 0,000 & 0,001 & 0,000 & & \\
\hline 2008 & 0,000 & 0,000 & 0,000 & 0,001 & 0,007 & 0,000 & 0,020 & 0,001 & 0,002 & 0,000 & 0,000 & & \\
\hline 2009 & 0,003 & 0,000 & 0,000 & 0,000 & 0,000 & 0,000 & 0,001 & 0,110 & 0,303 & 0,337 & 0,000 & & \\
\hline 2010 & 0,336 & 0,011 & 0,003 & 0,099 & 0,640 & 0,213 & 0,695 & 0,901 & 0,860 & 0,901 & 0,061 & & \\
\hline 2011 & 0,000 & 0,004 & 0,000 & 0,000 & 0,000 & 0,000 & 0,000 & 0,004 & 0,055 & 0,004 & 0,000 & & \\
\hline 2012 & 0,196 & 0,036 & 0,140 & 0,074 & 0,196 & 0,036 & 0,390 & 0,140 & 0,107 & 0,024 & 0,099 & & \\
\hline
\end{tabular}

So, alarge majority of averages mark significant differences, those display what those must say.

Moreover, throughout the speech given, the attitude we have had to analyze the factors of schools' disruption climate is merely causal, but we tried to point out that quality and school life are going together. They are, therefore, risk indicators, but not are direct causes. In this we agree with DHHS (2001) y Resnick (2004) among others.

\section{Summary of General Discoveries and Conclusions}

Considering “t” of Student, congruently the school's factors varies from a center to others, independently of socioeconomic characteristics, and size's center. This confirms previous researches like Olweus (1993), Withnew \& Smith (1994), Debarbieux (1999), Blaya (2001) and others. In fact there is a type of school culturalism condition that emphasizes the internal dysfunctions of formal education.

The three first clusters show the rates of violence are much bigger outside of the educational establishments where the rates of delinquency and violence are higher (Kaufmann and other, 1999), but the conflict is little incorporated into the educational institutions. So is not offering a confrontation image between these and the individuals as the US Annual Report on School Safety (1998) states.

The analyzed last four cluster's factors denote lack of cohesion (links with values and norms), in two facets institutional and interinstitucional. Consequently, general discoveries maded on case studies, and other researchers are confirmed respect those trends, but on quantity only a little.

To understand the globality of such acts in the education, through analyzed factors of the conflict with relationship to the quality of the teachings: 1) Relating the factors to each other, they reflect certain - not gravecontradictions among individual-institution-familycontext. 2) Inside of institutions, there is insufficient cohesion. This is due for bureaucratization, structuralism, overspecialization, etc.

Interrelating behavioral variables and certain factors (bureaucratization, structuralism, overspecialization) with the attitudes of the students, we underline the importance of the values in the decantation of the academic climate. So, if the educational system expels the human values, it could proceed as shall be demonstrating multiply confrontations and they could move to worse, although they are promoted in general from the socio-cultural 
context of where they are native the scholars. On the contrary, it is corroborated that to promote the education it is necessary an educational ethos (Hyndman \& Thorsborne, 1993; Olweus, 1989) that breaks the barrier of another factor that is the passivity of people (Rigby and Slee, 1993, y Rigby, 1996).

\section{Proposals}

While virtually all clusters are between points 2 and 3 , the Lickert (1-5)-type scale (Figure 4), we rated two clusters. The least important that both is "students incorporate disvalues into the classroom". If the groups, in which the subject is socialized, have deficiencies in values (order, punctuality, industry...) and global culture (functional illiteracy, anomie, atomie...), then a crash could occur with educational projects and coexistence plans of the school. This would cause an individual alumnus crisis hit, which probably show that they lead to discipline problems. That is consequence of the cultural malaise that surrounds schools (Philippe, 2002, 68), and these maladaptive behaviors are steps towards a social breakdown, the refusal to accept any kind of social authority (Trong, 2000, 32).

The group of issues more incidents are: "excessive bureaucratic activity in which teachers are involved". As the bureaucracy does not consider the primacy of person, relationships, affective, values, etc., it involves more organizational rigidity of schools. This causes the reduction of human action to a functionalist schema. This means anonymity, leading disavowal (insufficient authority of the teacher) and the subsequent rebellion of the student (or class-group), which begin with the interruption and continue with indiscipline.

Taking partial results of research reported in other publications (Peiró, 2005), we could systematize some trends in conjunction with the predominant factors (mentioned below: I, II, III, etc.). If the data in each case manifest a strong predominance of:

I. Disvalues incorporated, then educational guidelines could note the tutorials with students (axiological attitudes) or parents (values, customs).

II. Incoherence society-center, then: to encourage participation in the processes of the school and social volunteerism through NGOs or the like.

III. Poor informal education. To implement programs of conflict resolution, prosaically activities, promote acts of cooperation, attract communicativeness...

IV. Overspecilist teachers: recycling them who can teach values into lessons without manipulation.

V. Bureaucratization in center: To promote activities that encourage: a) Self-assertion and generate valuerelated climate; b) delegate tasks, procedures, etc., share responsibilities. c) To promote humanistic values.

VI. Structuralism: a) To provide spaces and times for informal meetings and positive personal relationships. b) To optimize the human relations climate. c) To practice the flexible grouping of students according their expressive goals. d) Monitoring "conflict" areas.

VII. Objectives: a) Promoting the diversification of the curriculum (not just concepts). b) Design and develop systematic programs that prevent learning gaps and adapt individualized curriculum. c) Developing standards together, according to the values of the school projects.

Therefore, to justify violence as innate, poverty is intermarry with crime is a myth that must be broken because it is ideological, it's a lie (Osorio, 2008, 47; Bleichmar, 2010, 35). It is a crisis of meaning (Debarbieux, 1999) a vacuum of values.

Like Guillotte (2003, 230), these relative to the school conflicting factors, cannot be solved if certain external persons - related with the tree first clusters- could be cooperate with teachers in their place. This aren't staff and therefore don't implicitly can work better than them in a direct support to the education of the civility of the students in the school".

As founds on variables of educational violence are similar the results of Barroso et al $(2001,171)$ who indicated to work the following trends: a) to acquire basic values; b) to careful the classroom climate, c) to imply to the class' group in the sense of the responsibility and taking of decisions.

Each of these proposals doesn't be exhaust the possible measures. Nor is it to develop a juxtaposition of those for each educational action. We must remember that if you missed the unity of the school, then we could be recovered that. Therefore, we should develop comprehensive and differentiated education plans to promote an academic peaceful-coexistence. Ethos could integrate all or part of said above in each cluster.

About to implement this, one of the important commitments of educators and teachers must to assume in their task consist of incorporating, as an explicitly way, the values placed in the educational and curricular projects. Those axiological maters are to make a more human life, able to fill with sense the existence, values that open possibilities so that it is given in our society a harmonicer peaceful coexistence. The own system facilitates this task when giving option to the taking of decisions in the school advice and educational teams (Domínguez et al. 1996 9).

In another part we also have analyzed programs and experiences with relationship to the school violence (Peiró, 2005). We have wide of references on the topic on Victoria Gov. (2011), which indicates there are a lot of researches on this theme. For example: the Sheffield University DFE Project, on healthy societies and healthy schools. Such systems, although they obtain some improvements, they are not lasting, being scarce their results. The lacks can explain to itself before the partial vision of the problem and these projects are short rehearsals (Whitney \& Smith, 1993). For these reasons we must consider the phenomenon like holistic, an understanding way. Fairly, this justifies that we are going well into for the perspective of the world of the values.

\section{References}

[1] Alanen, J. \& Storey, A. (2003). Sneaking up on Immigration Swindlers, Los Angeles Daily Journal, December 18. http://www.kcba.org/streaming/Documents/INTE-attachment3.pdf Consulted 2008/12/30.

[2] ANPE (2011). Informe 2010-2011 del Defensor del Profesor. National Association of State Teachers. Independent Trade. http://www.anpe.es/sin-categoria/2011/12/anpe-presenta-elinforme-2010-2011-del-defensor-del-profesor/ Consulted $18 / 12 / 2011$ 
[3] Arnaiz, P. and other (2003) Students in risk of social exclusion: The school integration of minority cultural groups in the region of Murcia. Bordón, vol. 55, n 1.

[4] Barroso, C.; Buxarrais, M. R., y Oret, C. La acción educativa en el medio social. CITE (2001) Conflicto, violencia y educación. Murcia, Cajamurcia.

[5] Blaya, C. (2001). Climat scolaire et violence dans l'enseignement secondaire en France et en Angleterre; en Debarbieux, C.; Blaya, C. (dir.): Violence à l'école et politiques publiques. París, ESF Éditeurs, pp. 159-177.

[6] Blaya, C. (2005) Factores de riesgo escolares. IX Reunión Internacional sobre Biología y Sociología de la violencia: Violencia y escuela. Valencia, Centro Reina Sofía para el Estudio de la Violencia.

[7] Castanedo, C. (1993) Valores educativos de profesores de EGB: al iniciar la carrera, al finalizarla y al trabajar en colegios. Doctoral thesis, Universidad Complutense de Madrid. Spain.

[8] CDC (2011). School Violence: Risk and Protective Factors. Centers for Desease Control and Prevention.

http://www.cdc.gov/violenceprevention/youthviolence/schoolviole nce/risk.html Consulted 20/12/2013.

[9] Coie, J.D., Dodge, K.A., Ferry, T. y Wright, V. (1991) The role of aggression in peer relations: an analysis of agresión episodios in boy's play groups. Child development, n 62.

[10] Debarbieux, E. (1999). La violence en milieu scolaire: Vol. 2. Le désordre des choses. Paris, ESF.

[11] Debarbieux, E. (2012). La violence à l'école: spécificités, causes et traitement. In CUSSON, M. (ed.) Traité des Violences Criminelles. Montréal: Hurtubise.

[12] Defensor del Pueblo Español (2000) Violencia escolar: El maltrato entre iguales en la ESO. Prepared by: C. del Barrio, E. Martín, I Fernández, L Hierro, I Montero, H Gutiérrez y E Ochaíta, commissioned by the UNICEF's Spanish Committee. Madrid: Publicaciones de la Oficina del Defensor del Pueblo. www.defensordepueblo.es/informes/espec99/maininfoa1 Consulted 2002/12/27.

[13] DHHS (2001). Youth violence: a report of the Surgeon General. US Department of Health and Human Services. www.surgeongeneral.gov/library/youthviolence/toc.html Consulted 27/11/2007.

[14] Dodge, K. A., \& Feldman, E. (1990) Issues in social cognition and sociometric status. In S. R. Asher \& John D. Coie (Eds.) Peer rejection in childwood. New Yor, Cambridge Studies.

[15] Dominguez, T. y otros (1996) Comportamientos no violentos. Propuestas interdisciplinares para construir la paz. Madrid, Narcea.

[16] Fernández, I. (1999). Prevención de la violencia y resolución de conflictos. Narcea, Madrid.

[17] Floyd, N. M. (1985) Pick on somebody your own sice: Controlling victimization. Pointer, 29 (2), pp. 9-17. See also the following website: Consulted 18/11/2007.

file://C:/Documents\%20and\%20Settings/Usuario/Escritorio/NOV EDADES\%20VIOLENCIA\%20ESCOLAR/ARGENTINArecompilaci\%F3n.htm.

[18] Furlan, A. (2003). De la violencia y la escuela. http://redie.ens.uabc.mx/vol5no2/contenido-furlan.html Consulted 18/11/2009.

[19] García Orza, J. (1995) Violencia interpersonal en la escuela. El fenómeno del matonismo. En Boletin de Psicología, 49, 87-103.

[20] Gento, S. (2003) Problemas de disciplina y aprendizaje en el sistema educativo. Madrid, Sanz y Torres.

[21] Guillotte, A. (2003) Violencia y educación. Incidentes, incivilidades y autoridad en el contexto escolar. Buenos Aires. Edit: Amorrortu editores S. A.

[22] Hanke, B.; Huber, G., \& Mandl, H. (1979). El niño agresivo y desatento, Buenos Aires, Kapelusz.

[23] Houbre, B. (2005). La violénce a l'écòle: perspectives et interventions. Université de Metz. Doctoral disertation. Consulted 18/11/2009.

http://www.ac-nancy-metz.fr/ia57/silenceviolence/Documents/ violencesenmilieuscolaireBarbaraHoubre.pdf.

[24] Hyndman, M., and Thorsborne, M. (1994). Taking Action on Bullying: Whole school and multi-stage approach to intervention and prevention in Proceedings of First International Conference on Peer relations: Conflict and Cooperation. Adelaide, Institute ofSocial Research, University of South Australia.

[25] INTO (2004). Guidance on Management Challenging Behaviour in Schools. Dublin, Irish National Teacher's Organization.
http://www.into.ie/NI/INTOStudentCentre/StudentPublications/G uide_managing_challenging_behaviour.pdf Consulted 28/12/2012.

[26] IVECE (2005) Formación para la convivencia. Guía para el profesorado. Generalitat Valenciana, Consellería de Cultura, Educació i Esport. Valencia (Spain).

[27] LAW (NEW) EDUCATION OF SPAIN. 12886. Ley Orgánica 8/2013, de 9 de diciembre, para la mejora de la calidad educativa.

[28] Mahasneh, A.M.M., \& others (2012). Misbehaviour in Jordanian Secondary Schools. Asian Social Science, Vol. 8, No. 6; May 2012.

[29] Marais, P. \& Meier, C. (2010). Disruptive behaviour in the Foundation Phase of schooling. South African Journal of Education, Vol 30:41-57. Consulted 27/12/2011. http://sajournalofeducation.co.za/index.php/saje/article/view/315/1 88.

[30] Morales Puertas, M. (2000) Convivencia, tolerancia y multilingïsmo en educacion intercultural de secundaria. Madrid, Nancea.

[31] Nakpodia, E.D. (2010). Teachers' disciplinary approaches to students' discipline problems in Nigerian secondary schools. International NGO Journal, Vol. 5 (6), pp. 144-151, July 2010 https://www.academicjournals.org/article/article1381827362_Nak podia.pdf Consulted 27/12/2011.

[32] OAVE (2009). El modelo pedagógico es la causa de la violencia escolar. Universidad nacional de Cuyo, Obervatorio Argentino de Violencia en las Escuelas. Consultado 22/10/2011. http://argentinainvestiga.edu.ar/noticia.php?titulo=\%93el_modelo _pedagogico_es_la_causa_de_la_violencia_escolar\%94\&id=778.

[33] Ochoa, A. \& Peiró, S. (2010). Estudio comparativo de las actuaciones de los profesores ante situaciones que alteran la convivencia escolar: el caso de Querétaro (México) y Alicante (España). REIFOP, 13 (4). Enlace web: http://www.aufop.com Consulted 22/10/2011.

[34] Olweus, D. (1978). Aggression in the schools. New York: Wiley.

[35] Olweus, D. (1993). Bullying at school: What we know and what we can do. Malden, MA: Blackwell Publishing.

[36] Olweus, D. (2005) Bullying en la escuela: datos e intervención. En Violencia y escuela. Valencia, Centro reina Sofía para el estudio de la violencia, pp. 13ss.

[37] Osorio, F. (2008). Violencia en las escuelas. Análisis de la subjetividad. Buenos Aires: Noveduc.

[38] Palomero, J. E. y Fernández, M. R. (2001). La violencia escolar: Un punto de vista global. Revista Interuniversitaria de Formación del Profesorado, 41, 19-38. http://www.aufop.com/aufop/uploaded_files/articulos/1247352775 .pdf Consulted 22/10/2006.

[39] Peiró, S. (1993) La educación del niño en riesgo. Situaciones marginales y negligencia. Fundamentos, problemática y lineamientos pedagógicos. Proyecto de la UNESCO: La infancia y la familia, 1990-95. Granada, Adhara-Unesco.

[40] Peiró, S. (1997). La escuela ante los abusos y malos tratos. Granada. Grupo Editorial Universitario.

[41] Peiró, S. (2001). Factores de violencia y calidad de la educación. VIII Congreso Nacional de Teoría de la Educación. Editado en: Núñez, L.; Romero, C. Evaluación de políticas educativas. Universidad de Huelva (España).

[42] Peiró, S. (2001.a-coord). Violencia en el aula, curriculum y valores. Alicante, ECU.

[43] Peiró, S. (2001.b-coord). I Jornadas sobre violencia en educación. Alicante, ECU.

[44] Peiró, S. (2002-coord). II Jornadas sobre violencia en educación: problemas desde la perspectiva del centro docente. Alicante, ECU.

[45] Peiró, S. (2003). La educación familiar como modelo para contrarrestar la violencia escolar. Revista Panamericana de Pedagogía, n 4, pp. 232-253.

[46] Peiró, S. (2004-coord). De la indisciplina y violencia al conflicto escolar. Propuestas educativas. RGV University press. Alicante.

[47] Peiró, S. (2005-coord). Terceras Jornadas sobre Violencia en Educación: perspectivas interdisciplinares de explicación e intervención pedagógica. Alicante, ECU.

[48] Peiró, S. (2005). Indisciplina y violencia escolar. Alicante, Instituto Alicantino de Cultura "Juan Gil Albert”.

[49] Peiró, S. (2006-coord.) Relaciones conflictivas y calidad educativa, Alicante, Edt. Club Universitario.

[50] Philippe, J. (2002). La libertad interior. Madrid, Rialp.

[51] Polit, D. y Humgler, B. (1997). Investigación científica en ciencias de la salud. México, MacGraw-Hill. 
[52] Resnick MD, Ireland M, Borowsky I. (2004). Youth violence perpetration: what protects? What predicts? Findings from the National Longitudinal Study of Adolescent Health. Journal of Adolescent Health, 35: 424. e1-e10.

[53] Rey, R. del y Marchesi, A. (2005). La opinión de los profesores sobre la violencia en los centros. Madrid, IDEA y CIE-FUHEM.

[54] Rigby, K. (1996). Bullying in schools. And what to do about it. London: Jessica Kingsley.

[55] Rigby, K. \& Slee, P.T. (1991). Bullying among Australian school children: Reported behaviour and attitudes towards victims. Journal of Social Psychology, 131, 615-627.

[56] Tillmann, K. J. (2005). Factores de riesgo de la violencia escolar: factores socioculturales, IX Reunión Internacional sobre biología y sociología de la violencia: Violencia y Escuela. Valencia, España, Centro Reina Sofía para el Estudio de la Violencia.

Notes.

ihttp://www.exceptionalkids.com.au/education/behaviour_problems2.htm http://www.asti.ie/pdfs/Policy\%20Documents/IndisciplinePolicy.pdf http://www.scotland.gov.uk/Publications/2004/11/20233/46417

${ }^{i i}$ Richard, S. (1987) El niño maltratado. Buenos Aires, Humanitas; p. 47-

48. The concretion of such formulations can be read in the section 2 . The experience of the crisis in those subjects of the education, of the report of Gonzalo Jover: "La crisis de la sociedad actual”, en el SITE (2001)

Conflicto, violencia y educación. Murcia, Cajamurcia; pp. 36ss.

iiiiThere is just consider the following references: Bernard van Leer Foundation (1997) Niños afectados por la violencia, en Boletín informativo, 11 marzo, La Haya. Bremberck (1973) Sociología de la educación, Barcelona, Paidós. Brown, W. y DeLapp, L. (1995) Stopping the violence, Sacramento, California State Legislature. Sanmartín, J. (2000) Las claves de la violencia. Barcelona, Ariel. Hurrelmann, cfr. Hanke, Huber y Mandl: El niño agresivo y desatento, Buenos Aires, Kapelusz. Nobles, Wade-W. (1989) Congressional Hearings on America's Young Black Men: Isolated and in Trouble. Washington, D.C., July, 1989, Institute for the Advanced Study of Black Family Life and Culture. Oakland. Revista Infancia y Sociedad, 1989. Estudio de la Subseceratría de la Generalitat Valenciana (1999/2000). Zuckerman, B \& others (1989) Niños en riesgo: problemas sociales y médicos, México, Interamericana.

${ }^{\text {iv } T r a c e y ~ H a w t h o r n e: ~ B u l l y i n g: ~ A n ~ o v e r v i e w ~ o f ~ i n t e r n a t i o n a l ~ r e s e a r c h ~}$ into peer abuse in schools and strategies to alter this form of abusive behaviour.http://www.exceptionalkids.com.au/education/behaviour_prob lems2.htm

vAristotle uses the name "syllogism" in such a wide sense that it embraces all kinds of reasonings. It defines this way by this sentence: "syllogism is a speech (logos) in wich, for the fact of putting some data, it is necessarily one previously different from the positions, for the fact of having been put" (First Analytic I, 1, 24b).

${ }^{\mathrm{v}}$ We hypothesized that the averages are equal, with a confidence level of $95 \%$. Thus a " $t$ " less than $0.05(5 \%)$ is taken as the averages are significantly different, that is, that the difference is not due to the statistical chance.

${ }^{\text {vii }}$ We have shown in red the indexes corresponding to questions that show a significant variation in the stocking, among the suitable level of the trust of $95 \%$.
[57] Trong, B. (2000). Violences Urbanines. París, Bayard.

[58] USA (2000, 2001, etc.). Annual Report on School Safety. Washington, DC: U.S. Departments of Education and Justice.

[59] Victoria Government. Department of Education and Early Childhood Development (2001) http://www.education.vic.gov.au/Documents/school/teachers/healt h/respectfulrel.pdf Consulted 22/10/2008.

[60] Whitney, I. \& Smith, P.K. (1993). A survey of the nature and extent of bullying in junior, middle and secondary Schools. Educational Research 35, 3-25.

[61] Willis, P. (1979). Spa $\beta$ am Widerstand. Gegenkultur in der Arbeiterchule. Frankfurt/Main, Syndikat.

[62] Whitney, I. \& Smith, P. K. (1993). A survey of the nature and extent of bullying in junior/middle and secondary schools. Educational Research, 35, 3-25. 